\title{
History of Forest Management in Nepal: An Analysis of Political and Economic Perspective
}

\author{
Yogesh Ranjit ${ }^{3}$
}

\begin{abstract}
Forest management, a kind of practical application, is technical, scientific and economic principle of forestry to maintain and management. The history of forest management in Nepal is closely associated with the political and economic history of the country. Any change in economic and political and economic situation also directly or indirectly changes the forest management practices of Nepal. The main objective of the study is to analyze the historical development of forest management of Nepal from political and economic perspective. It is a historical and descriptive nature of the study i.e. fully based on the secondary sources of data and information in order to have better understanding about the political and economic effects on forest management practices. The key political changes in the country have been divided into five different periods and thereby notably changes in forest management practices which is starting from the state control and exploitation of forests to people's participation, protection, and conservation, sustainable, and scientific forest management. People's participation in forest management has been widely accepted in legal as well as policy level.
\end{abstract}

Key words: History, Change in political system, Economic benefits, Forest management,

\section{Introduction}

Forest management is defined as the practical application of technical, scientific, and economic principles of forestry to maintain and manage the sustainability of forests. Forestry is an integral part of the rural livelihood of Nepal that covers 44.8 percent of the total land area of Nepal (MoF, 2019). Forests were one of the major sources of revenue and export earning of Nepal until 1960's. So, there was a popular slogan known as 'Nepalko Dhan, Hariyo Ban' (Nepal's wealth, Green forests). But, in the last four decades, forests area in quality, quantity and density have decreased considerably especially in the Terai and Siwalik regions due to uncontrolled and unsustainable use of forests and forest products to meet the need of timber, pole, fuel wood, fodder, grass, leaf litter, other non-timber forest products (NTFPs) and biomass for growing population and huge demand from growing urban centers. Besides $75 \%$ of the country's energy requirement is met by fuel-wood (Parajuli, 1997) and 70 percent to 80 percent fuel-wood, fodder and small timber requirements of the people living in the Terai is being met from farm forestry sources (Rai, 1997).

\footnotetext{
${ }^{3}$ Dr. Ranjit is an Associate Professor at Central Department of Economics Tribhuvan University. Email: Yogeshr777@yahoo.com
} 
Like most of other developing countries, Nepal has also lost a significant amount of its forests in the last hundred years (1850s-1950s) especially due to the expansion of farmlands, government revenue (Hobley et. al., 1996), uncontrolled and unsustainable use of forests and forest products. Consequently, a large tract of evergreen forest of Terai and Siwalik regions has been destroyed to meet the food, fuel wood, fodder, over grazing and timber for growing population in the region and also growing demand from urban centers and development programmes of the government etc. moreover, the loss of forests started during 1950's along with malaria eradication and resettlement programme of the government for the huge migrated people from Hills to Terai.

\section{Objective and Methodology}

The main objective of the study is to analyze the historical development pattern of forest management of Nepal from political and economic perspective. It is a historical and descriptive nature of the study. Hence, the study is fully based on the secondary sources of data and information. It involves the review of books, booklets, research reports, proceedings, forest policy, acts, regulation, and directives. A meaningful consultation with experts, forest officials and members of forest related institutions, and organization in the field of forest management is also undertaken in order to generate more ideas and better understanding about the timeline of historical development pattern, procedure, results, political and economic effects on forest management of Nepal.

\section{Historical Development of Forest Management Practices}

The key political and economic changes in the country have been divided into five different periods and thereby notably changes in forest management practices of Nepal as following -

\section{Pre-Unification of Nepal (before 1768)}

Prior to 1768, Nepal was consisted of a number of small kingdoms, principalities and tribal areas. The economy of all those states was highly based on land and forests due to the lack of other natural resources, trade and communication. All lands and forests were state owned and peasants had to pay one-half of the products to the states as rent (Regmi, 1971). So, before unification of Nepal, the nation was governed by different rulers of different dynasty like Kirats, Lichivis, Devas and Mallas for several centuries based on chronicles, inscriptions and travelogues by foreign travelers (Bhattarai and Khanal, 2005). In the ancient history of Nepal, Lichchhavi Dynasty is considered as a golden age due to the decentralized administrative policies like Gosthi and Panchali (a committee of village elders) that supported communal organizations like Kipat. During the Lichhivi period, royal orders were normally issued that allowed people to harvest trees and other NTFPs for domestic purposes. The local bodies like Panchalis were given authority to settle the matters of the use of forest and forest products (Tiwari, 1989). States taxes known as Sinkar on the exports of wood products and herbs were also levied during the Lichchhavi period. Ancient inscriptions indicate that authority in forest matters were largely a communal matter with dictates from King Shiva Dev in the middle of the fifth century empowering village councils to oversee use. Households were allowed to fill up to 40 trees each year for home construction and charcoal making, but commercial use was banned according to the inscriptions (Gautam, 1991). 
The Malla Dynasty also followed the system of Lichchhavi in the eleventh century and the historical records indicate that one Malla queen established and expanded the temple forest network in the Kathmandu Valley in the sixteenth century with provisions that banned all hunting, gathering and fires. Malla rulers also gained revenue from India by exporting timber, wax, honey, birds and elephants collected in the forest in the Terai. Besides, they were already beginning to import $\mathrm{Sal}$ logs from the southern forests due to a growing shortage of good timber in the Valley. By the early eighteen century, forest management practices for temple, royal land, and commercial holding in the Valley were clearly articulated and actively implemented. The history of forest management has been distinctly different in the Kathmandu Valley with the middle Hills and Terai (Poffenberger, 2000).

Similarly, during the Malla period, royal orders were frequently issued to protect forests of different areas of Kathmandu Valley like Kritipur, Soyambhu, Balaju, Changu, Gokarna, Bajrajogini as Ban Gadh (forest moats) and people in those areas were prevented from cutting trees. Any violations of the royal order were immediately punished as per the given rules and regulation. The responsibilities of forest protection and other forest related activities were also assigned to some State functionaries like Vaskaradhikart, and Basota in Lichhivi Period and Mahane in Malla Period. Moreover, there was a strand law relating to forest use and management in the royal orders of king Ram Shah of Gorkha (a small but powerful kingdom of Nepal) during 1606-1633. The similar type of policy of forest use and management was continued during the time of Prithivi Narayan Shah (a king of small kingdom namely Gurkha) who unified of Nepal Kingdom in 1768 and afterwards.

The history of forest management in the Middle Hills was totally different from the history of Kathmandu Valley. While Kathmandu Valley had gained sophisticated cultures, the Hills remained populated by tribal communities. So, most of the indigenous hill tribes of Nepal held all their land and forests under a form of Kipat which is an ancient type of land tenure without any legal title, common among the Limbu ethnic group of the mountains of Nepal. However, Kipat system was very common and popular land holding system in the Hills of Nepal before unification of Nepal (i.e.1743) which gradually changed with political changes. In the Hills, virtually every one lived through subsistence agriculture that means the almost all agricultural production was consumed locally (Schroeder, 1985).

The history of forest management in the Terai differs sharply from the experience of the Kathmandu Valley and Hill forests. The dense $S a l$ forests of the Terai with a substantial number of wild animals like tiger, elephants, rhinoceros etc. resisted settlement and logging for centuries due to the prevalence of endemic malaria throughout the region. Only the Tharu and several other tribal communities, who had developed some resistance to the disease, resided in the area practicing hunting, gathering and farming. So, by the time of Nepal's unification in the late eighteenth century, the forest resources of the Terai were seen as important source of revenue for the government. Hence, Pre-unification period of Nepal was the time of abundance of forests and forest resources. 


\section{Post-Unification of Nepal (1768-1846)}

Prithivi Narayan Shah took over the three Kingdoms of the Kathmandu Valley in 1768 as the last conquest during his regime. The unification process was further continued by the Shah's descendants. In those days, there was no any particular forest policy so that there were no any formal forest management activities and programmes. In fact, there was no need to regulate the forests as the size of population was small and forest resources were plenty. On the contrary, the policy at that time was to encourage the people to convert the forestland to agriculture land in order to increase the land-tax revenue of the government. Therefore, in absence of state regulation and control of forests, the people live in and around the forests and collect what they need from the forests for their daily subsistence. But occasionally some royal orders were issued to regulate specified forest area for special purpose (Shrestha, 1999).

Prithivi Narayan Shah also started a system of distributing land and forests to army officials in the forms of Jagir and senior office holders in the form of Birta to bring into cultivation (Mahat et. al., 1986). The Birta system was very common practice in the Hills of Nepal. So, in the process of developing cultivated lands, a lot of forests and common pasture lands were destroyed. Prithivi Narayan Shah also made alliances with Gurung, Magars, and other Hill tribes and allowed them to retain communal holding of lands and forests as Kipat system.

Besides, a number of indigenous ethnic groups origin of a particular areas owned lands and forests on a communal basis without any legal title like Kipat. No doubt, the Kiratis (Limbu) of the eastern-hill region are the most important Kipat owning community in Nepal. Some other communities like Danuwar, Sunwar, Tamang, Sherpa, Kumales and Lepchay etc. also held land and forests under such tenure system in both the eastern and western hill regions (Regmi, 1971). The state, in fact, had no any authority to reallocate Kipat lands as Birta or Guthi or to dispose of vacant Kipat holdings. However, compared to other systems, very little land was under Kipat in several parts of Hills of Nepal. Moreover, another ancient type of indigenous collection management system is Shingo Newa system which means locally appointed in the Khumbu region of eastern Nepal with responsibility for allocating forest resources and ensuring that individuals adhered to the rules for forest use. In this system, the Sherpa community appoints forest guards in order to protect and care of forest products. A number of authors have used traditional and indigenous forest management as synonymous.

However, Kipat is an ancient, traditional and communal land holding system in Nepal which changed gradually with political changes. In most of the places, the Kipat system was abolished after the conquest by the Gorkhalies. Consequently, most of the Kiraties joined the enemy in the China War during 1788-93 due to the loss of their traditional system. Besides, the non Limbu communities could not remain under that communal system and most of their holdings were converted into Raikar (Ragmi, 1971). In this way over time period, indigenous systems of communal land and forest management were gradually supplanted by feudal systems of control (Ghimire, 1998). Some five types of land tenure system in Nepal were identified during that period like Kipat (communal lands, a legal standing before unification of Nepal), Jagir (assigned to the army official or government employees), Birta (granted by the government to high officials), Guthi (institutional lands usually religious) and Raikar (state owned but privately cultivated lands) (Joshi, 1989).

Similarly, after unification of Nepal, the government had established administration regulations centralizing the timber trade, selling of wax and certain other forest products with 
the new order in 1799. By 1886, the Terai forests were classified as those with high commercial value (Sira), low commercial value (Jhora) and protected forests. Government officials carefully regulated the system of exports (Poffenberger, 2000). So, after unification of Nepal, a lot of land and forests in the forms of Jagir and Birta grants distributed by giving more emphasis on the conversion of forests into agriculture lands. A very little interest was paid in forest protection and management process. Hence, the post-unification period led to active land reclamation policy and clearing of forests in the Hills.

\section{Rana Regime (1846-1950)}

From 1846 to 1950 for a period of 104 years, Nepal was ruled by a hereditary dynasty of Rana Prime Ministers and Shah Kings remained as only the figureheads and king only by name. In that period, forests of Nepal were exploited to allow for the expansion of agriculture and government revenue generation. Exploitation of forest was formulized through the legal judicial process under the rule of Jung Bahadur Rana, first Rana Prime Minister, during 1846-1877 (Hobley et. al., 1996). The promulgation of these rules for forest exploitation coincided with an increased removal of trees and forest products for sale to India. During Rana Regime, forest sector of Nepal was administered under the feudal system. The successive Rana governments took the policy of extending the cultivation in Terai plains by clear felling the forests for increase land tax and agricultural production. Although the Rana government recognized indigenous system of forest management, generally administration worked against sustainable management. Large areas of forests were allotted as Birta in Terai and Shorhana in the Hills to the members of extended Rana families as favour by the government (Rai, 1997). The Birta system was a common practice in the Hills and also became more common in the Terai during the Rana regime. That Birta forestland was also cleared for cultivation that was tax free and heritable (Shrestha, 1999). At the same time, massive exploitable of the State forest in Terai were carried out especially for timber export to British India. Policy and practice in that period allowed for unregulated exploitation of the valuable Terai forests. But most of the parts of Hills and Mountain forests were inaccessible and remote from the markets so that the Hills forests were relatively free from commercial exploitation although they did fall victim to the exigencies of agricultural expansion.

Besides, many communities in the Hills and Mountain regions were aware of the need to have sustainable management of forests and forest products because of their dependence on them. So, many rural communities in those regions have also established their own system for protecting and managing local forests on their own initiatives for common benefits. Under that system, Hill communities kept a patch of forest known as Rani Ban (queen's forest) with clearly defined the locally accepted rules and fixed regularized forest use and group of beneficiaries (Shrestha, 1996). The use of such forests was permitted only for a few months each year and the rest of the time it be remained unused to fully regenerate. The Rani Bans were strictly indigenous and are still managing their forests successfully irrespective of state's laws and ownership (Joshi, 1997). The main activity practiced under such indigenous management system was a seasonal removal of forest products in order to meet the subsistence needs. These indigenous management systems were often relatively sustainable (Shrestha, 1999). This may be the practice that has evolved into Nepal's current community forestry system (Belbase \& Regmi, 2002). 
Similarly, the traditional forest management system was operated for considerable time by the local level involving an unofficial functionaries nominated by the rulers like Subba, Mukhiya and Jimmbwals collectively called Talukdar (unofficial functionary) in the Hills and Mountains. Talukdars had responsibility only for local forests during the Rana period. The Talukdars used to regulate the use of forest by local communities for their need of small timber, pole, fuel-wood, fodder, grass, leaf litter, grazing and other such activities (Shrestha, 1999). Basically, in Rana Period, forests were under the charge of Bada Hakims, an administrative head of the district. But the Bada Hakim just issues the permission for major tree-felling activities so that the responsibility of local forest management and utilization ultimately come directly to Talukdars in the Hills and Mountain. They were able to administer the forests quite effectively and provide a reasonable amount of protection and control. The local people collected what they need from the forests without paying any fees. But some sort of gift (Theki) in return to the functionary had become customary (Mahat et. al., 1986). These systems worked well in those periods because firstly the demand on forest resources was limited due to low population and secondly the strong Rana rules used to recognize these systems (Shrestha, 1999).

In fact, forest organization in Nepal began around 1880 A.D. with the establishment of a Ban Jaanch Adda (Forest Inspection Office). However, at the national level, a Central Forest Management Office was opened only in 1924 which were looked after one of the Rana Generals and Kath Mahal Office (Timber Office) was established in 1927 to work on Forests (Patil, 1996). During the Rana's rule, it is also told that there were strict forest rules. At that time, to cut even a small tree without permission of the authority was prohibited. Anyone found having cut a tree without permission might be jailed or heavy punished. One who cut a Bijaya Sal (Pterocarpus Marsupium) tree could even be punished death penalty. Until the 1950's, forest administration in the country hardly existed and it was under the charge of land revenue and general administration officials who had the responsibility to settle as much land as possible (Mahat et. al., 1986). So, all matters related to forests were integrated with the then land tenure system and land revenue policy of the government. The ruler's orders, notifications and legal code formed the legislation of that time and all these were related to agricultural land and revenue policy. However, till1950, the forests were not as degraded as they have become after that (Rai, 1997).

In fact, there was a strong and significant British influence in the forest management practices and forest exploitation activities in Nepal. When a British forest advisor, J. V. Collier (1925-1930) was appointed to advice on the regulation and utilization of the Terai forests, it started exporting of Sal (Shorea Sobusta) from Nepal to India (Hobley et. al., 1996). He undertook intensive felling in the forests of western Terai of Nepal. He even advocated clearing all the forests of few Eastern districts of Nepal like Morang and replacing it with cash crops. So, following the recommendation made by Collier, the forests in Morang district were cleared for settlement and agricultural (Bhatia, 1999).

Likewise, as part of Nepal's contribution to the World War - I effort, timber for railways was granted by the government to the British India at free of royalty charge and thereby increase in rate of forest exploitation in high speed (Hobley et al., 1996). Besides, two forest offices were established out of which one was in the Terai to regulate timber extraction in Terai area and another was in Kathmandu responsible for Hill forests. Similarly, Indian contractors who were familiar with forest harvesting across the border were brought into work on these forests. Hence, the system of forest exploitation remained centered around the use of Indian contractors 
and thereby forest exploitation took place severely. Intensive felling of forests by Indian contractors took place in the Terai up to the end of World War - II (Bhatia, 1999). The Nepalese had little control over the exploitation of their forests and flow of forest profits to the British in India. Hence, forestlands were cleared for agriculture as and when required and trees were felled as desired. So, there was no organized forest management in Nepal prior to 1941 (Rai, 1997).

In 1941, necessity for forest management was highly recognized and forest service was created in Nepal with the British forest adviser E. A. Smithies (1941-1947) who had spent several years with the Indian Forest Service. He advised for the attractive of the new department of forests based on the Indian Forest Service and its foresters were trained in India at the Imperial Forestry School at Dehra Dun. Hence, upon his advice, Department of Forests (DoF) was established in 1942 with three regional and 12 divisional forest offices. His emphasis was on regulated tree felling, fire conservancy, stand improvement and management of the forest through Working Plan and forest exploitation was carried out under a series of working plans from the forests of several Terai districts on the ground of similar lives and procedure of Indian Forest Service and regulation of Indian Forestry (Hobley et al., 1996).

The DoF was established as a state agency in 1942 to manage the forests and forest resources of Nepal (HMG/N, 1976). In 1947, the forest institute or school was set up under the forest service to produce mid-level technical training to forester (Palit, 1996). Historically, forest management by the department was protection oriented and efforts were made to make foresters powerful. The private forests were nationalized with the Private Forest Nationalization Act-1957 to strengthen state control over the forest management (HMG/N, 2057). This act legally centralized the authority of forest management in the Terai (lowlands) and Hills under state control, although local communities were informally managing patches of forests adjoining to their settlements. Furthermore, special rights to issue permits even to harvest trees for household purposes were assigned to forest officials with the promulgation of the Forest Act-1961. This Act gave further authority to forest officer to arrest forest offenders without warrant. Moreover, Forest Protection Act-1967 was promulgated to provide additional power to state foresters. It also established one-person special court run by the Divisional Forest Officer. However, the focus of the Department was to manage forests without involvement of the local people (Kandel, 2017).

On the contrary, the Rana rulers did not stopped continuing exploitation of forests and forest products and also widely extended it in the Terai. In the process of increasing cultivated lands, a lot of forested and common pasture lands were destroyed. The Birta system became more common in the Terai during the Rana period (before 1951). By the end of Rana government in 1951, one-third of the countries farmland and forests were held under Birta land grants, out of which 75 percent belonged to members of the Rana family (Regmi, 1978). Similarly, to maintain the sovereign authority of the state, the Rana made a policy to privatize the Kipat lands to collect taxes and registered most of the Kipat lands on the name of the influential persons of the community. So, it can be said that the loss of forestlands in the Hills of Nepal is not due to collection of wood and fodder for domestic uses but due to wide spread farming throughout most of human history (Bajrcharya, 1983). Hence, the Rana period led to active reclamation of forestland, massive clearing of forests and peaked timber exports to India due to commoditization of forest resources and concentration of rights over forests in the hands of the ruling class and other courtesans. 


\section{After Independence (1950-1988)}

Following the democratic revolution of 1951, the feudal Rana rulers were overthrown and new government took an initiation to organize the utilization, protection, and management of forests by enlarging the forestry organization (Shrestha, 1999). In 1951, a forest officer Robbe visited Nepal in order to prepare forest policy, legislations and forestry organization. He noted the problems of forest protection, deforestation, afforestation, soil erosion, and soil conservation. He also strongly recommended for implementation of Working Plan of E. A. Smythies (Palit, 1996). However, the Post-Rana period also continued commoditization of forest resources.

In 1957, the first major and bold step taken by the democratic government concerning the management of the forestlands was the enactment of the Private Forest Nationalization Act1957 and Birta Abolition Act -1959 in order to nationalize all forests for preventing their further destruction. The main objectives of the Act were to end the feudal land tenure system like Birta, Jagir or Raiker and bring the all forestlands of the country under the jurisdiction of the forest department for its better utilization, protection, and management. The Act also provided only 1.25 ha. in the Hills and 3.25 ha. in the Terai as private forests (Bhattarai and Khanal, 2005) ${ }^{4}$.

Then, communal responsibility for forest management disappeared and communities having no stake in forest preservation and management. Consequently, forests were converted into 'Open Access' as common property resource. However, But, following the Act, the government was unable to manage the forests effectively due to the lack of requisite infrastructure in both technical and administrative. In short, at the time of forest nationalization, the state was totally unable to control, protect, and manage the forests of the country as it lacked the necessarily institutional capacity (Palit, 1996). Besides, many feudal landlords remained in control of forest resources and access to them. Although several management plans were drawn up to facilitate commercial management in Terai area, these plans were not implemented due to aforesaid reasons. Although, in 1959, the first Ministry of Forest was established covering the entire country unfortunately, state control of the forests through the Act was failed primarily or particularly successive (Hobley et. al., 1996). However, Till 1950, the forests were not as degraded as they have become after that (Rai, 1997). Unfortunately, the process of deforestation and forest degradation rate were high especially during sixties and seventies (Dahal, 1994).

Due to failure of the democratic movement and thereby restoration of the power of monarchy in the early 1960's, a new party less system called Panchyat was introduced and soon after the Forest Act-1961 was enacted. The Act sought to restore government administration, registration, demarcation and control over national forests. It also defined the duties of the DoF, listed forest offences, and prescribed penalties as well (Mahat et al., 1986). This acts also made provisions for handing over forest resources to the newly formed Panchyat, which had far reaching consequences for local control of resources. The Act categories four different types of forests as shown in given table 1.

\footnotetext{
${ }^{4}$ The Act in brief says, 'Forests constitute an important part of the national wealth and that it is expedient to prevent the distribution of national wealth and to nationalize private forests for their adequate protection, maintenance and utilization for the welfare of the people and the country' -Private Forest Nationalization Act-1957.
} 
Table 1: Category of Forests as per the Forest Act - 1961

\begin{tabular}{|c|l|l|}
\hline SN & Types of Forest & \multicolumn{1}{c|}{ Interpretation } \\
\hline 1 & $\begin{array}{l}\text { Panchayat } \\
\text { Forests (PFs) }\end{array}$ & $\begin{array}{l}\text { Panchayat forests is any part of government forests of Nepal which had } \\
\text { been kept barren or contained only stumps that could be handed over by } \\
\text { HMG/N to the care of the village Panchyats for the welfare of the village } \\
\text { community on the prescribed terms and conditions }\end{array}$ \\
\hline 2 & $\begin{array}{l}\text { Panchayat } \\
\text { Protected Forests } \\
\text { (PPFs) }\end{array}$ & $\begin{array}{l}\text { Panchayat Protected Forests is any part of government forest of Nepal } \\
\text { which could be handed over to the Panchayat for protection and } \\
\text { management purposes. }\end{array}$ \\
\hline 3 & $\begin{array}{l}\text { Religious } \\
\text { Forests:- }\end{array}$ & $\begin{array}{l}\text { It is a part of govt. forest located in any religious spot could be handed } \\
\text { over to any religious institution for protection and management purposes. }\end{array}$ \\
\hline 4 & Contract Forests & $\begin{array}{l}\text { Any patch of government forest which had neither trees nor sporadic trees } \\
\text { could be handed over by HMG/N on contract basis to any individual or } \\
\text { institution for the protection of forest products and their consumption but } \\
\text { ownership of the forest land would remain with the government and } \\
\text { control could be resumed whenever the government deemed it necessary. }\end{array}$ \\
\hline
\end{tabular}

Source: HMG/N, 1961.

But the Act had only little impact on those forest areas that is distant from Kathmandu and inaccessible areas where local people continued to use the forests for subsistence needs, regarded of their legal status and forest legislation (Palit, 1996). However, the Forest Act-1961 legitimated Panchayat(s) the way for later changes in legislation and provided the environment in which community forestry or Participatory Forest Management could emerge (Hobley et al., 1996).

Similarly, the government passed the Forest Protection Act-1967 that provided the forestry official judicial power. Ideologically, until early 1970s, the legal regime relating to forestry in Nepal was normally based on the Indian Forest Act-1927 (Bhattari and Khanal, 2005). The Act, however, had little impact on forest protection in the Hills where local people continued to use the forests for their needs regardless of their legal status.

In 1973, an Institute of Forestry was established under the umbrella of Tribhuvan University. An important change in forest legislation began in response to the National Forestry Conference-1974 held in Kathmandu. In that conference, a community-oriented group of foresters working in the various districts strongly favoured for people to be involved in forestry protection and management work that became later known as Community Forestry. Realizing the importance of people's participation in forest management, the National Forest Plan-1976 accepted the need of people's participation that was the first government document to accept the need for people's participation in forest protection and management work.

In 1978, a serious and revolutionary wave was made in forestry sector with the emergence of the Panchayat Forests (PFs) and Panchayat Protected Forests (PPFs) Rules-1978 based on the amendment of Forest Act-1961 in order to handing over of accessible government forests to village Panchayat as a community forests. The PFs and PPFs rules allowed for the transfer of responsibility for forest protection and management from the government to the local Panchayat as PFs and PPFs (Joshi, 1993). Actually, it was a first written document of Nepal as a major policy guideline of forestry sector that formally recognized the involvement of local communities in protection, management, development and utilization of forests and forest 
products. The plan further considered the forests as property of society as against the prior stand it as national property. Moreover, it is no doubt to say that this plan laid a foundation for scientific forests management in Terai and Hills as well. People could cooperate through private, community or Panchayat level and increase participation in afforestation programmes ${ }^{5}$.

According to the Rules within the concerned village Panchyat boundary, each village Panchayat is eligible only for 125 ha. of government degraded forestlands for the creation of Panchayat Forest while only 500 ha. of well forestlands can be handed over as Panchayat Protected Forest based on the 'Working Plan' (Operation Plan) prepared by Divisional Forest Office. Similarly, the forest products from PFs could be sold to people of concerned village Panchayat at a price fixed by village Panchayat. If in excess, these could be sold to people from other village Panchyats. In the case of PPFs, the price of forest products will be fixed by the government but the people of the concerned village Panchayat are entitled to fuel wood, fodder, grass and medicinal herbs at free of cost. All income from the sale of forest products from PFs go to the fund of the concerned village Panchayat out of which 50 percent should be spent on protection, development and plantation of PFs. But in the case of PPFs, all such income first goes to Government treasury and upon the recommendation of Divisional Forest Office through the conservator of forests that the village Panchayat had performed well with regards to the protection and management of the forests, the government will release or give subsidy equivalent to 75 percent of the total amount of the income to the village Panchayat. But village Panchayats were prohibited to carry out many activities in PFs and PPFs like handing over, selling or mortgaging the forests, cultivating fruits, orchard, constructing building and any other land use except allowed by Working Plan.

But, the success was very limited with handed over only a small fraction of the total forest areas more of which was further degraded or lost during these days. The major reason was the lack of a clear definition of user group. Forests were not handed over to the actual users who protecting the forest or who could protect the forests. However, the legislation can be considered as bold with a major shift in forestry policy and the communities are empowered to manage the adjoining forest resources to meet their daily needs of fuel wood, fodder, grass and small timber. At the top most, the PFs and PPFs Rules-1978 made some positive effects to mitigate the negative effects of the Private Forest Nationalistion Act-1957 especially the disincentives to manage resources in a sustainable manner.

Similarly, following the success in Referendum in 1979, Panchayat politicians and elites became much actively engaged in their politics but not to consolidate forest protection and management activities. So, not much progress could be made in forest handing over and management (Shrestha, 1999). At the same time, the government of Nepal declared its forest sector policy first time in the Sixth Five-year Plan (1980-1985) that emphasized community participation in the management, conservation and utilization of forest resources. However, the year 1987 was a watershed in community forestry as First National Workshop on Community Forestry held in Kathmandu that recommended the concept of forest user groups (FUGs). Consequently, the 1988 amendment to the PFs and PPFs rules-1978 adopted the concept of the

${ }^{5}$ The plan wrote as 'To make people aware of, involve in and partner to protect, produce and better utilize the country's forest through people's cooperation from private individuals, community of Panchayat level in protecting the forest' - HMG/N, 1976. 
'User Group' by citing the Decentralization Act-1982 and Decentralization Rules-1984 that was later incorporated into the Master Plan for the Forestry Sector-1988. Hence, this workshop provided a valuable contribution to the development of master plan for forestry sector and formulation of Forest Act-1993 as well.

\section{After: 1988 onward}

The Master Plan for Forestry Sector (MPFS)-1988 provided a long term comprehensive and systematic development plan of the entire forestry sector by setting up medium and long term objectives for 22 years (1988-2010). The medium-term objectives under priority of the plan are like promoting people's participation and developing the legal framework to enhance the contribution of individuals, communities and institutions in development, management and conservation of forest resources; strengthening the organizational framework, and developing institution in the forestry sector (HMG/N, 1988). Similarly, the long-term objectives under priority are like meeting people's basic needs for timber, fuel-wood, fodder, grass and other NTFPs on a sustainable basis; creating opportunities of income and employment generation with establishment of forest based industries; protecting land against degradation by soil erosion, landslides, floods, desertification and other ecological disturbances; conserving ecosystems and genetic resources; phase-wise handing over of all accessible Hill forests to the communities, and retraining the entire staff of the MoF for new roles as advisers and facilitator. The MPFS also equally addresses the issue of women participation of one-third of any user committee's members. However, the major objective under priority is to meet people's basic needs of forest products on a sustained basis and to promote people's participation in the development, management and conservation of forestry resources ${ }^{6}$.

However, the success was limited with handed over only a small fraction of the total forest area more of which was further degraded or lost during these days. Till that period, only 2 percent of the potential community forests area has come under management that indicates that the management of the remaining potential community forest area will take at least another 400 years if the speed of activities remains the same (Joshi, 1993). The major reason for disappointing results was the impractical nature of the Rules which failed to create an environment for the full participation of all users. They did not provide a clear procedure for the transfer of authority for the protection, utilization and management of forests to the real users. This failure is amply demonstrated by the decrease in forest area from 6.5 million ha. in 1965 to 5.5 million ha. in 1990 (Shrestha, 1996).

Following changes in the whole political system of Nepal in 1990, the community forestry regulations were also revised (HMG/N, 1990). As the Constitution of the Kingdom of Nepal follows the principles of decentralization, it provided the legal mandate to local user groups for protection, utilization, and management of forests ${ }^{7}$.

6 The MPFS states, 'The present uncontrolled use of forest and forest products will be gradually eliminated by promoting the user as manager of forests and forest near the village will be managed with people's participation. The policy highly supports the development and management of forest resources through the active participation of individuals and communities to meet their basic needs and embarks on the phased handing over of all accessible Hill forests to communities to the extent that they are able and willing to manage them'- $H M G / N, 1988$.

${ }^{7}$ The new Constitution states, 'The State shall give priority to the protection of environment and prevention of its further damage due to physical development activates by increasing the awareness of the 
Then, the government started to hand over a particular patch of forestlands to a particular FUG for conservation, management and better utilization. The District Forest Officer (DFO) was deputed to form FUGs, hand over the forests and provided technical assistance. The cost of developing community forestry was to be partly subsidized by the government, although all tangible benefits derived from such development was to go to the user groups (Palit, 1996). Similarly, the Eight Five-year Plan (1992-1997) emphasized the need of decentralization and strengthen the role of FUGs as local level development organization.

The Forest Act-1993 is the latest forest legislation promulgated by royal decree on the $5^{\text {th }}$ January and came into force from $3^{\text {rd }}$ April, 1993 that legally recognized the process of community forestry and also legally empowered the local communities to protect and manage their community forests (HMG/N, 1993). The new Forest Act-1993 was solely concentrated on forest management and user groups ${ }^{8}$. A user group is defined as an autonomous corporate body and enterprise registered with DoF as it can do any type of business. The Act also classified the forests of Nepal into two broad categories i.e. National forests and private forests on the basic of control and ownership of forest land. The cultivation of trees and other forest resources on private land is known as private forests which is free to utilize, sell and distribute them and there is no area limit of private forests. There is no compulsory to register the private forests with the DoF. But such registration makes it easier for the private forests holder to get all sorts of assistance provided by the DoF (Bhattarai \& Khanal, 2005). The national forest is further categorized into the five different types like - Government forests (a part of national forests managed by HMG/N), Community forests (a part of national forests which is handed over to user groups for its development, conservation and optimal utilization for collective benefits), Protected forests (a part of National forests declared by HMG/N), Leasehold forests (a leased forests to any institutions), and Religious forests (any forests handed over to a religious body).

However, following the commitments for the Earth Summit-1992, the Act was first amended in 1998 making various provisions that included penalizing FUGs members for acts committed against the 'Operational Plan' and 'Constitution' of FUG and to spend at least 25 percent of their fund for the development, conservation and management of the community forests for global carbon emission mitigation and biodiversity conservation and only the rest 75 percent of the fund can be spent for rural development activities.

Again, the Second National Workshop on Community Forestry was held in 1993 that focused on issues related to organizational structure of the DoF, bottom-up planning, human resource development, training and net-working of FUGs and forestry staff, involvement of NGOs as a key to the success of community forestry programme. Moreover, this workshop recognized and emphasized the need for post-formulation support to FUGs and provided valuable inputs for the formulation of forest regulation. Consequently,

The Forest Regulations-1995 was used that basically focused on the determination of forests on various types, procedure of handing over the community forests, preparation of

general public about environmental cleanliness, protection of rare species of wildlife, forests and vegetation'-in Article-26:4, HMG/N, 1990.

${ }^{8}$ The forest Act states 'A community forest is a part of the national forest which is handed over to the CFUG for management, conservation and use of forests without affecting environmental and community interests' -1993. 
constitution and operational plan of FUGs, registration of FUGs, collection, sale and distribution of forest products, establishment of the forest based industries, prohibited functions in the forests, transportation of forest products, maintenance of records, and operation of FUG's fund, withdrawal of community forests and re-handover (HMG/N, 1995) etc.. It also indirectly advocated a change in the role of forestry staff from policing job to a facilitator. Besides, the government also provided Community Forestry Directives-1995 and Operational Guidelines1995 for effective implementation of the Acts and Regulations. In 2000, the HMG/N has made a decision on new concept of forest management in Terai, Inner Terai and Siwalik that includes collaborative management of national forests on the basis of land slope planning approach, conservation, management of degraded and open forest area in Terai and Inner Terai, and Siwalik forestlands.

The Ninth Five-year Plan (1997-2002) emphasized the appropriate management and utilization of forest resources through maintaining a balance between the environment and development. The plan stipulated various forestry programmes for employment generation, poverty alleviation, raise the productivity of forestlands and its management by adoption a liberal economic system to encourage the private sector.

The Third National Workshop on Community Forestry held in 1998 was an instrumental in developing the national vision of community forestry for 15 years which identified the role of different stakeholders in achieving the mutual cooperation and coordination of different stakeholders, improvement of bio-diversity, role of facilitators like central govt., local govt., and NGOs), creation of income and employment opportunities for poor and disadvantaged groups; equal participation of all members of FUGs in access and decision making process, and equitable distribution of benefits from community forests.

In 2000, the government implemented the Forest Sector Policy-2000 that prescribed to handover the barren and isolated forestlands of the Terai, inner Terai and Churia hills as community forests with the preparation of 'Operation Plan' and forest products will be used based on annual increment. Similarly, the government will collect 40 percent of the earnings from the sale of surplus timber of community forests of Terai, Inner-Terai and Siwalik for the implementation of the programme. The large patch of forests in blocks in the Terai and innerTerai will be managed by the collaborative solidarity of the local users, local political bodies (VDCs and DDCs) and the government but not to local communities as community forests and users under collaborative solidarity will get only 25 percent of the income from the sale of surplus forest products and the rest 75 percent income will go the income of the government.

The government also introduced Guidelines for Inventory of Community Forest-2000 that regulates the harvesting of forest products from community forests by restricting the FUGs not exceeding 30 to 60 percent of mean value annual allowable.

The Fourth National Workshop on Community Forestry held in Kathmandu from 4-6 August, 2004 provided guidelines to link community forestry to good governance in forestry, livelihood promotion and sustainable forest management as second generation issues of community forestry in meeting the goals of Tenth Five-year Plan (2002-2007). Moreover, the workshop went one step ahead by focusing on world-wide emerging issues of poverty reduction through community forestry.

With the successes of the community forestry approach, several complementary models of participatory community based forest management came in operation. Leasehold forestry (LF) 
is for poorest of the poor for poverty reduction. Only isolated and degraded forestland is handed over to them. The leasehold forest rules have two provisions to allocate forest areas either to firms or for a group of poor households. Usually a leasehold forest group is composed of 10 households as members. According to the rules, interested parties may apply for leasehold forests. The Department of Forests has the authority to handover Leasehold forests for 30 years upon payment of the lease rent, which is NRs. 20 per Bigha ( 0.65 hectares) for the Terai and NRs. 1 per Ropani (0.05 hectare) for the Hills (Kandel, 2017).

The government also formulated 'Collaborative Forest Management Policy in April, 2000 and Collaborative forest management guideline-2010 as a way to manage government-managed national forests as per approved forest management plan to improve economic opportunities, livelihoods, and ecological balance etc. The government receives 75 percent of the income from the sale of firewood and timber, and VDC/DDC and local forest users collectively get 25 percent. The 'Fifth National Workshop on Collaborative Forestry' held in Kathmandu on $6^{\text {th }}$ and $7^{\text {th }}$, June, 2014 with the slogan of 'Scientific Forest Management: Foundation for prosperity'.

The community forestry international workshop was held in Pokhara from 15-18 September, 2009 on the theme of 'Think globally-acting locally: Community forestry in the international arena'. The workshop focused on state and community partnerships in forestry, climate change and environmental services, social inclusion, democratic, and economic development.

The Fifth National Workshop on Community Forestry held in Kathmandu from 9-11 November, 2008 with the slogan of New destination of community forests for transformation of forestry sector. Similarly, the Sixth National Workshop on Community Forestry held in Lalitpur from 16-18 June, 2014 with the slogan Community Forestry for Sustainable Development and Prosperity.

The fourteenth periodic plan (2073-76) aims to transform Nepal into a middle-income economy by 2030 by achieving annual economic growth of 7.2 percent. The plan envisages making the forestry sector a significant contributor to this aim and gives priority to several programmes and projects in the forest sector. Again, Scientific Forest Management Guideline2014 was implemented to increase the productivity of forestry sector and production of forest products through sustainable forest management. Moreover, Forest policy-2015 and Forest Decade programme-2015 to 2025 were also formulated.

Forest Sector Strategies-2016 to 2025 identifies eight strategic pillars like sustainably managed resources and ecosystem services; conducive policy process and operational environment; responsive and transparent organizations and partnerships; improved governance and effective service delivery; security of resource use by the community; private sector engagement and economic development; gender equality, social inclusion and poverty reduction; and climate change mitigation and resilience. The strategies aims to deliver five major outcomes ranging from sustainable production and supply of forest products; improvement of biodiversity, watersheds and ecosystem services; increased contribution to national economic development; inclusive and accountable forestry sector institutions and organizations to climate-resilient society and forest ecosystems (MoFSC, 2016).

National Forest Policy-2019 is implemented with the objectives of increasing production and productivity of forests, environmental services, biodiversity conservation and its sustainable uses etc. The basic information of multiple forest management models of Nepal in 2018 is shown in the given table. 
Table 2: Data Related to Multiple Forest Management Models of Nepal in 2018

\begin{tabular}{|c|l|c|c|c|}
\hline SN & Types of Forests & $\begin{array}{l}\text { No. of User } \\
\text { Groups }\end{array}$ & Area (in hec.) & $\begin{array}{l}\text { No. of } \\
\text { Households } \\
\text { Involved }\end{array}$ \\
\hline 1 & Community Forests & 22,266 & $22,37,670.52$ & $29,07,871$ \\
\hline 2 & Collaborative Forests & 30 & $76,01,2.26$ & $8,64,015$ \\
\hline \multirow{2}{*}{3} & Leasehold Forests (disadvantage group) & 7484 & 43317 & 71753 \\
\cline { 2 - 5 } & Leasehold Forests (business) & 22 & 640 & NA \\
\hline 4 & Private Forests & 2458 & 2360 & NA \\
\hline 5 & Religious Forests & 36 & 2056 & - \\
\hline 6 & Conservative Forests & 10 & 190809.43 & - \\
\cline { 2 - 5 } & Proposed Conservative Forests & 06 & 137833.49 & - \\
\hline 7 & Conservative Area & 20 & $34,419.75$ & - \\
\hline
\end{tabular}

Source: DoF, 2018.

\section{Conclusion}

Before 1950s, the ruling class focused on exploitation and state control over forest land. They adopted a policy of distributing forest land in various ways to convert to agricultural land and generate income from the converted land as rent or taxes. But, during1950-1970, the government expanded its role in forest production and marketing. However, in the 1970s, the government started considerable focus on protection, management, biodiversity conservation, and environment. Community forestry regulations were introduced jn the late 1970's with the provision to hand over the forests to local communities for protection, management and sustainable use. The government also intended to encourage rural communities to grow trees on their private lands. In late 1980s, MPFS-1988 has been a major milestone in the forestry sector development in Nepal. Moreover, with Forest Act-1993 and Forest Regulation-1995, people's participation in forest management has been widely accepted in legal as well as policy level. FUGs started working with respecting women participation, social inclusion in decision making and equity in benefits distribution etc. FUGs are functioning well enough for socio-economic development and environmental protection. However, it is not free from some specific problems and criticisms on different aspects. The major challenges of CFM in Nepal are how to make meaningful involvement of women, poor and disadvantaged groups for their better access, rights and benefits for their livelihood. Besides, some second generation issues like good governance, livelihood promotion and sustainable development are also following in community forestry programme in the beginning of $21^{\text {st }}$ century. 


\section{References}

Bajrcharya, D. (1983). Deforestation in the food/fuel context: Historical and political perspectives from Nepal, in Mountain Research and Development, 3: 227-240.

Belbase, N. \& Regmi, D. C. (2002). Potential for conflict: Community forestry and decentralisation legislation in Nepal, ICIMOD, Kathmandu, Nepal, February.

Bhatia, A. (ed.) (1999). Participatory forestry management: Implications for policy and human resources development in the Hindu-Kush Himalayas, ICIMOD, Kathmandu, Nepal.

Bhattarai, A. M. \& Khanal, D. R. (2005). Communities, forests and law of Nepal: Present state and challenges, Federation of Community Forestry Users, Kathmandu, Nepal.

Dahal, D. R. (1994). A review of forest user groups: Case studies of eastern Nepal, ICIMOD, Kathmandu, Napal.

DoF (Department of forest) (2018). Community Forestry Bulletin, Division of Community forestry, Department of forest, Babarmahsl, Kathmandu, Nepal. Vol. 18

Gautam, K. H. (1991), Indigenous forest management systems in the Hills of Nepal, Master's Thesis, Australian National University, December.

Ghimire, K. (1998). Forest or farm? The policies of land hunger in Nepal. Manohar Publisher, New Delhi, India.

HMG/N (1957), Private Forest Nationalization Act-1957, His Majesty's Government, Kathmandu, Nepal.

HMG/N (1961). Forest Act-1961, Nepal Rajpatra (Gazette), His Majesty's Government, Kathmandu, Nepal.

HMG/N (1976). Forest Act-1976, Nepal Rajpatra (Gazette), His Majesty's Government, Kathmandu, Nepal.

HMG/N (1988), Master Plan for the Forestry Sector, His Majesty's Government, Ministry of Forest and Soil Conservation, Kathmandu, Nepal.

HMG/N (1990), The Constitution of Nepal-1990, His Majesty's Government, Ministry of Law, Justice and Parliamentary Affairs, Law Book Management Board, Kathmandu.

HMG/N (1993), Forest Act-1993, His Majesty's Government, Ministry of Forest and Soil Conservation, Kathmandu, Nepal.

HMG/N (1995), Forest Regulation-1995, His Majesty's Government, Ministry of Forest and Soil Conservation, Kathmandu, Nepal.

HMG/N (2000), Forest Sector Policy-2000, His Majesty's Government, Ministry of Forest and Soil Conservation, Kathmandu, Nepal.

Hobley, M.; Campbell, J. Y.; \& Bhatia, A. (1996), Community forestry in India and Nepal: Learning from each other, Series no. MNR 96/3, ICIMID, Kathmandu, Nepal.

Joshi, A. L. (1989). The prevalent pressure on natural resources and its management through the local community, Patan, Nepal.

Joshi, A. L. (1993). Effects on administration of changed forest policies in Nepal, Paper presented at the Workshop on Policy and Legislation in Community Forest, RECOFTC, Bangkok, Thailand.

Kandel, K. R. (2017). Current status of community forestry in Nepal, Community Forestry Division, Department of Forest, Kathmandu, Nepal.

Mahat, T. B. S.; Griffin, D. M.; \& Shepherd, K. R. (1986), Human impact on some forests of the Middle Hills of Nepal: Forestry in the context of the traditional resources of the state, in Mountain Research and Development, 6(3):223-334.

MoF (Ministry of Finance) (2019). Economic Survey - 2018 / 19, Government of Nepal, Singha Darbar, Kathmandu, Nepal. 
MoFSC (Ministry of Forestry and Soil Conservation) (2016). Forestry Sector Strategy-2016/25, MSFP, Babarmahal, Kathmandu.)

Palit, S. (1996). Comparative analysis of policy and institutional dimension of cCommunity forestry in India and Nepal, a Discussion Paper, MNR 96/4, ICIMOD, Kathmandu, Nepal.

Parajuli, D. P. (1997). Analysis of forest policy in Nepal, in S. Gyawali, K. Baral and C. Khatiwada (eds.). Prabhat, Institute of Forestry, Pokhara, Nepal, Vol: 5 pp 9-16.

Poffenberger, M. (eds.) (2000), Communities and forest management in South Asia, WG-CIFM, DFID and IUCN.

Rai, S. N. (1997). Management of tropical forests in Nepal in S. Gyawali, K. Baral and C. Khatiwada (eds.). Prabhat, Annual Publication, Institute of Forestry, Pokhara, Nepal, (5).

Regmi, M. C. (1971). A study in Nepali economic history (1768-1845), Manjushri Publishing House, New Delhi.

Regmi, M. C. (1978). Land tenure and taxation in Nepal, 1(4), Ratna Pustak Bhandar, Kathmandu, Nepal.

Schroeder, R. F. (1985). Himalayan subsistence system: Indigenous agriculture in rural Nepal, Mountain Research and Development, 5: 31-44.

Shrestha, K. B. (1996), Decentralized planning and people's participation in decision making in Nepal, Paper presented at the National Seminar on Strengthening Participatory Democracy through Decentralization, Political Science Association of Nepal, Kathmandu, Nepal, March, 14-15.

Shrestha, K. P. (1999), Community forestry evolution: Concept and policy, a paper presented in international training course, RECOFT, Kathmandu, Nepal, (18 Sep-10 Oct), 1999.

Tiwari, K. B. (1989), Nepalko ban byabasthako aitihasik simhalokan, Abarta Press, Kathmandu. 